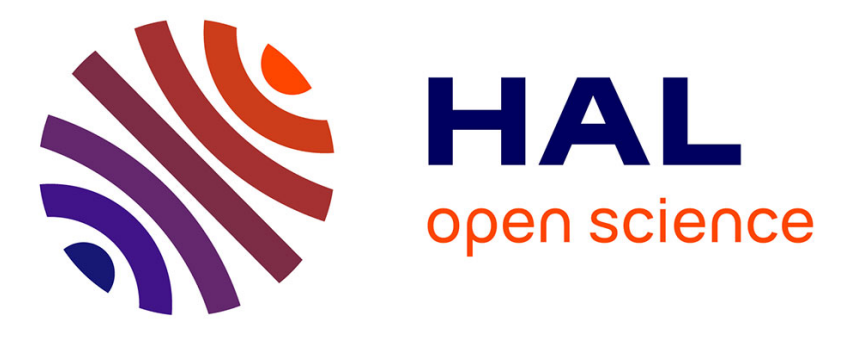

\title{
Attitude towards reciprocity as a motive for oocyte donation
}

\author{
Guido Pennings, Célia Ravel, Jean-Maxime Girard, Mathilde \\ Domin-Bernhard, Veerle Provoost
}

\section{- To cite this version:}

Guido Pennings, Célia Ravel, Jean-Maxime Girard, Mathilde Domin-Bernhard, Veerle Provoost. Attitude towards reciprocity as a motive for oocyte donation. European Journal of Obstetrics \& Gynecology and Reproductive Biology, 2018, 225, pp.194-198. 10.1016/j.ejogrb.2018.04.038 . hal$01795807 \mathrm{v} 3$

\section{HAL Id: hal-01795807 \\ https://hal-univ-rennes1.archives-ouvertes.fr/hal-01795807v3}

Submitted on 21 Sep 2018

HAL is a multi-disciplinary open access archive for the deposit and dissemination of scientific research documents, whether they are published or not. The documents may come from teaching and research institutions in France or abroad, or from public or private research centers.
L'archive ouverte pluridisciplinaire HAL, est destinée au dépôt et à la diffusion de documents scientifiques de niveau recherche, publiés ou non, émanant des établissements d'enseignement et de recherche français ou étrangers, des laboratoires publics ou privés. 


\section{Attitude towards reciprocity as a motive for oocyte donation}

Guido Pennings, PhD, Bioethics Institute Ghent, Department of Philosophy and Moral Science, Ghent University, Blandijnberg 2, B-9000 Gent, Belgium. Tel: 092643970

Guido.Pennings@Ugent.be Corresponding author

Célia Ravel, MD, PhD, Laboratoire de Biologie de la Reproduction-CECOS, Université de Rennes1, INSERM U1085-IRSET, Hôpital SUD, 16 Bd de Bulgarie, 35000 Rennes, France. Tel: + 33299265916 Celia.RAVEL@chu-rennes.fr

Jean-Maxime Girard, MD, Université de Rennes1, Laboratoire de Biologie de la Reproduction-CECOS, Hôpital SUD, 16 Bd de Bulgarie, 35000 Rennes, France. Tel: + 332 99265911 Jeanmaxime.GIRARD@chu-rennes.fr

Mathilde Domin-Bernhard, MD, Laboratoire de Biologie de la Reproduction-CECOS, Hôpital SUD, 16 Bd de Bulgarie, 35000 Rennes, France. Tel: + 33299265911

Mathilde.DOMIN.BERNHARD@chu-rennes.fr

Veerle Provoost, PhD, Bioethics Institute Ghent, Department of Philosophy and Moral Science, Ghent University, Blandijnberg 2, B-9000 Gent, Belgium. Tel: 092644104 Veerle.Provoost@Ugent.be

The authors report no conflicts of interest.

Attitude towards reciprocity as a motive for oocyte donation

\section{Abstract}

Objective: Finding out whether patients would be motivated by reciprocity when considering donating oocytes to others.

Study design: This is a prospective monocentric study in the CECOS of the Centre Hospitalier Universitaire (CHU) of Rennes (France) on the opinion of patients regarding reciprocity.

Couples who had a child with donor sperm were asked whether they would consider oocyte donation as a way of giving something back.

Results: Twenty six couples and one man answered the questionnaire. About half of the respondents (49\%) felt that they should contribute to the system from which they benefitted. Although the patients would benefit from a reduction in waiting time, this advantage was only 
important for one in four persons. The only items on which the answers between men and women were significantly different concerned the results of the donation: women would think more often about the potential recipient and the child and they more often wanted to know whether children were born from their donation.

Conclusion: The results show that beside altruism, reciprocity may be an important moral reason for people to donate gametes.

Keywords: altruism; anonymity; oocyte donation; reciprocity; sperm donation

\section{Introduction}

Many European countries are struggling to recruit a sufficient number of oocyte donors. In some countries, media campaigns are started in order to increase awareness. However, the shortage of gamete donors, and oocyte donors in particular, is not going down. On the contrary, due to the increase of recipients (mainly older women) the gap between demand and supply becomes larger. A frequently suggested solution is payment. However, within Europe, payment for body material is forbidden. Moreover, also ethical objections can be raised against commercial transactions of body material. We believe that within accepted ethical limits, new recruitment systems can be tried. One such system is built on the basic moral rule of reciprocity: people who voluntarily accept to benefit from a system should make a contribution to that system according to their capacities. Transferred to the context of gamete donation, this rule implies that persons who received gametes should, if possible, also donate gametes. This can be done by setting up a system in which the partner of the infertile person donates gametes. This system, also called mirror gamete donation, can be organized in different ways and has been applied in clinics in Bologna (Italy) and Eindhoven (The Netherlands) with great success [1, 2]. The Centre Hospitalier Universitaire of Rennes (France) applies a similar system. In this centre, the possibility to donate eggs is discussed systematically with couples who come back for a subsequent child with donor sperm. If they decide to donate, their waiting period is reduced with about 6 months, which is approximately half of the normal waiting time. No other incentives are offered.

At the time of the research project, the French law only allowed people who already had a child to become donors. The law has changed in January 2016 also allowing persons without 
children to donate. Moreover, oocyte donors can now also preserve a number of eggs for themselves if they do not have a child already [3].

In France, the operating principle of gamete donation is solidarity. The initial concept was based on the idea that a couple that already has a child goes to the French national gamete biobank (CECOS: Centre d'études et de conservation des oeufs et du sperme humains) to help another couple. The method of recruitment is mostly relational as sterile couples sensitize their friends or family. By recruiting a donor, they allow faster treatment of couples registered on the waiting list before them [4].

The reciprocity system met with fierce opposition from different groups, amongst which professionals who considered this a violation of the altruism principle that should underlie the donation [5]. Although we believe that the proposal is perfectly acceptable on ethical grounds, we know nothing about how patients think about this proposal. The present study wanted to find out to what extend reciprocity and fairness play a role in the decision making of patients who themselves benefitted from sperm donation in the past.

Material and methods

This is a prospective monocentric study in the CECOS of the Centre Hospitalier Universitaire (CHU) of Rennes (France). The questionnaire was given during the consultation to couples who came back for a subsequent child with donor sperm. Couples in which the woman was known to be unsuitable as a donor (because of age or medical or genetic contra-indications) were excluded. From November 2014 to December 2015, 30 couples were invited to participate in the study. Questionnaires were received from 26 women and 27 male partners resulting in a response rate of $87 \%$. The study was stopped before the change of the law because the altered conditions would make it difficult to interpret and compare the data.

For the opinion statements, responses were combined into three categories (totally agree/agree, neutral, disagree/totally disagree). Analysis was conducted using Fisher's Exact (Cytel Studio StatXact-8) to compare the distribution of categorical variables and the independent t-test (Statistical Package of the Social Sciences, SPSS version 23) to compare the mean age between two categories of a particular attitude (totally agree and agree versus neutral, disagree and totally disagree) or reason to participate in the reciprocity system (very important and important versus neutral, unimportant and very unimportant).

The study was approved by the local Ethics Committee of the CHU of Rennes (advice 14-67). 


\section{Results}

Demographic characteristics

The respondents had a mean age of 33 years and were highly educated (close to $60 \%$ had a university degree). Most had a full or part-time time job and had one child. The majority knew people whose children were donor conceived but only a few people knew other women who had donated eggs (Table 1).

\section{Reciprocity}

About half of the respondents (49\%) felt that they should give something back (Table 2). About $40 \%$ believed that everyone should contribute to the system of gamete donation. No significant differences between men and women were found regarding the items related to reciprocity. Respondents who felt that they should give something back more often thought that everyone should contribute to the system compared to those who did not hold this feeling $(14 / 25,56.0 \%$ versus $7 / 27,25.9 ; p=0.047)$. Furthermore, when compared to others, a considerably lower proportion of respondents who had this feeling of a duty to give something back thought that they would often think of the woman who would receive their eggs $(2 / 26,7.7 \%$ versus $10 / 27,37.0 \%$; $\mathrm{p}=0.019)$ or of the child who would result from their eggs $(0 / 26,0.0 \%$ versus $9 / 27,33.3 \%$; $\mathrm{p}=0.002)$. They also more often stated that their belief in the reciprocity system was a motivation to come to this centre $(21 / 25,84.0 \%$ versus $10 / 27$, $37.0 \% ; \mathrm{p}<0.001)$.

If they would step into the reciprocity system, the overwhelming majority would do so to help others $(94 \%)$, to give something back (60\%), to obtain the sperm they needed (28\%) and/or to get faster treatment (24\%). (Table 3) An overwhelming majority (83\%) disagreed with the statement that they would not donate if they would not get sperm in return and three out of four $(75 \%)$ disagreed with the statement that they would not donate if they would not receive faster treatment. Only two men would rather wait longer than have their partner donate. No women shared this view. The majority (two thirds) of the respondents did not perceive their potential donation as an act that was mainly meant to benefit the male partner. There were no statistically significant differences in reasons to participate in the reciprocity system according to level of education or professional activity of the respondents.

Relationship with recipient and offspring

Less than one in four would think often about the recipient of their (partners') eggs. About $17 \%$ would think often about the child born from their (partners') donation. A significant 
difference exists between men and women in this regard: significantly more women would think about the recipient (42 vs. $37 \%$ ) and about the offspring (30.9 vs. 3.7\%). About one in four would like to know whether a child was born from their donation and one woman would like to know the child. Many more women than men were interested to know whether a child was born due to the donation (42.3 vs. $7.7 \%, \mathrm{P}=0.009)$.

Anonymity

The majority of the patients (69\%) saw anonymity as a necessary condition for them to donate. Two persons (4\%) believed that the child born from their eggs should be able to know them. The respondents with a college or university degree more often considered anonymity as a necessary condition to donate compared to the group with a lower educational level (24/30, 80.0\% versus 10/50, 50.0\%; $\mathrm{p}=0.034)$. Respondents who felt that they should give something back less often considered anonymity a necessary condition to donate $(14 / 26,53.8 \%$ versus $22 / 26,84.6 \%$; $\mathrm{p}=0.034)$.

Beliefs about the donation

About $36 \%$ considered the donation as an extra burden on top of their own treatment and more than $40 \%$ saw it as a big effort. Patients who held a college or university degree significantly more often thought that donating eggs was an extra burden compared to respondents who held a lower degree $(19 / 21,90.5 \%$ versus $15 / 30,50.0 \%$; $p=0.003)$.

About one in five (19\%) thought that the donation would reduce their chances of getting pregnant and two women (4\%) thought that donating eggs would have negative effects on their health.

Disclosure and approval of others

Patients would generally be open to their social environment about their donation. Five respondents $(10 \%)$ would not tell anyone that they had used donor sperm and about three (6\%) would not tell anyone that they/their partner had donated eggs. The majority (69\%) believed that their friends and family would approve of their donation if they would find out. Patients who were unemployed significantly less often thought that, if told, their friends and family would approve of them donating eggs $(2 / 7,28.6 \%$ versus $34 / 45,75.6 ; \mathrm{p}=0.023)$.

Respondents who would not tell anyone that they or their partner donated eggs were significantly older (mean of 38.33 years) than the others (mean of 33.09 years; $p=0.032$ ).

\section{Discussion}


Within the field of gamete donation, and by extension donation of body material, one focusses almost solely on altruism as the primary value. However, other moral considerations, such as fairness and reciprocity, may also constitute valuable principles to found the transaction [6]. Our data show that about half of the patients held a personal moral conviction of reciprocity and $40 \%$ believed that there is a general obligation for patients to contribute to the system they benefitted from. The statements about the reciprocity system indicate that although people get a reduction in waiting time in return for their (possible) donation, the majority would not donate in order to receive this reduction. They seemed to consider their part mainly in relation to the sperm they already received or would receive. This may explain why the incentive was not decisive. However, one should be cautious since it is possible that another or stronger incentive would have a larger impact on the decision. One such adaptation could be to reserve a number of eggs for immediate fertilization and replacement so that the donor would benefit from a higher success rate (IVF compared to IUI) and a complete abolition of the waiting time. Moreover, although the majority did not donate with the reduction in mind, about one in four (28\%) indicated that their reason to participate in the reciprocity scheme was to obtain the sperm they needed and $24 \%$ to obtain treatment sooner. The low importance attributed to the incentive can be explained by the fact that only five persons (10\%) were concerned about getting sperm in time. With a mean age of 33 years, they may have thought that they still had some time left before their chances would really go down and also because they already had one child.

The patients showed a high degree of openness both about using donor sperm and donating donor eggs. There are a number of studies about telling the child about the donor conception but there are no systematic studies about telling others. The studies are also very difficult to compare since in many countries the recipient population mainly consists of single women and lesbian couples. Since these persons are excluded from donor insemination by law in France, we looked for studies with data on heterosexual couples exclusively or separately. In general, French couples seem to be open about the donor conception towards their child [7]. It is important to know that the counselors in the CECOS centres council directively for parents to be open. A recent study on disclosure to the offspring in French couples who used donor sperm also contained information on telling others [8]. 85\% of those who responded had told other people (mainly family and friends) about the use of donor sperm. That leaves $15 \%$ who had not told others but this percentage is likely higher since there was a response rate of $65 \%$ 
and people who intend to keep the treatment to themselves are more likely to refuse participation in a study, as the authors themselves remarked.

Donor anonymity is imposed by law since 1994 in France. In a 2006 study among a large sample of parents with a child from donor sperm (a sample very similar to ours), more than $90 \%$ was in agreement with donor anonymity and less than $10 \%$ wanted to change the law on this point [7]. Also in another study on French parents, $96 \%$ of the respondents agreed with the 'anonymous and free' rule of the current system [9]. The findings of our study confirm the wish of parents to maintain donor anonymity.

It is interesting to note that the only three questions on which the answers were significantly different between men and women concerned the results of the donation. Women would think more often about the potential recipient and the child and they more often wanted to know whether children were born from their donation. These findings are consistent with data from oocyte donors elsewhere [10]. However, it is very difficult to compare data from different studies since both the type of donor (known, commercial, identifiable etc.) and the legal setting vary. For instance, the majority of volunteer donors $(86 \%)$ in a study with identifiable donors wanted to know if their donation had succeeded and $49 \%$ would think about the child resulting from their donation [11]. The fact that these donors were identifiable, contrary to our sample, may have affected their attitudes. Men seem far less implicated and seem to distance themselves from the potential gift of their partner. This attitude may express their ideas about the importance of the genetic link: the contribution of their partner is closed (finished business) after the donation. Not wanting to know about the outcome and not thinking about child and recipient means that no relationship is established. The men probably expects the sperm donor to adopt the same attitude towards their gift. Lowering the importance of the genetic link indirectly strengthens their position as social parents.

Limitations of the study. This is a small sample of patients in a specific setting. It is not possible to extrapolate these findings to other oocyte donors since the elements of the context (previous child from sperm donation, waiting time ...) are crucial. Moreover, we should be aware of the possibility of social desirability in answering the questions. Regrettably the guarantee of anonymity did prevent us from finding out which patients eventually also decided to donate. However, we do know that in the total group of egg donors in this centre about $45 \%$ are recruited within the reciprocity system [12]. As such, it is an important source of extra donors. 


\section{Conclusion}

The data indicate that 'giving something back' is a moral norm for about half of the patients who benefitted from donor sperm in the past. This norm may be an important element in the decision to donate. The data also indicate that a reduction in waiting time is not considered as important by the majority of the patients. Two possibilities exist: either the incentive was too weak (not attractive enough) or patients wanted to give something in return for what they had received. In the latter case, they do not give in order to receive an advantage and increasing the advantage would not make much difference.

\section{References}

[1] Ferraretti AP, Pennings G, Gianaroli L, Magli MC. Semen donor recruitment in an oocyte donation programme. Hum Reprod 2006; 21(10): 2482-5.

[2] Pennings G. Mirror gametes donation J Psychosom Obstet Gynaecol 2007;28:187-191.

[3] France, Ministère des Affaires Sociales, de la Santé et des Droits des Femmes. Arrêté du 24 décembre 2015 pris en application de l'article L. 2141-1 du code de la santé publique et modifiant l'arrêté du 3 août 2010 modifiant l'arrêté du 11 avril 2008 relatif aux règles de bonnes pratiques cliniques et biologiques d'assistance médicale à la procréation. Journal officiel de la république française. 2016, 8 janvier 2016.

[4] Ravel C, Berthaut I, Bresson JL, Siffroi JP, Genetics Commission of the French Federation of CECOS. Prevalence of chromosomal abnormalities in phenotypically normal and fertile adult males: large-scale survey of over 10,000 sperm donor karyotypes. Hum Reprod 2006; 21 (6): 1484-9.

[5] NVOG [Dutch Society for Obstetrics and Gynaecology] (2014) [Gamete donation in a system of fair reciprocity]. Dutch. http://nvogdocumenten.nl/uploaded/docs/Gameetdonatie $\% 20 \mathrm{in} \% 20 \mathrm{een} \% 20$ systeem $\% 20 \mathrm{van} \% 20 \mathrm{faire} \% 2$ 0wederkerigheid\%2014-7-2014.pdf

[6] Pennings G. The central role of altruism in the recruitment of gamete donors. Monash Bioeth Rev 2015; 33: 78-88.

[7] Jouannet P, Kunstmann JM, Juillard JC, et al. La majorité des couples procréant par don de sperme envisagent d'informer l'enfant de son mode de conception, mais la plupart souhaitent le maintien de l'anonymat du donneur. Andrologie 2010; 20(1): 29-36. 
[8] Lassalzede T, Paci M, Rouzier J, et al. Sperm donor conception and disclosure to children: a 10-year retrospective follow-up study of parental attitudes in one French center for the study and preservation of eggs and sperm (CECOS). Fertil Steril 2017; 108(2): 247-53.

[9] Doumergue M. Dons, parentés et représentations sociales. Ph.D. thesis, Université de Lyon. 2016 HAL archives-ouvertes.fr

[10] Bracewell-Milnes, T, Srdjan S, Shabana B, et al. Investigating psychosocial attitudes, motivations and experiences of oocyte donors, recipients and egg sharers: a systematic review. Hum Reprod Update 2016; 22: 450-65.

[11] Lampic, C., Skoog Svanberg, A, Sydsjö, G. Attitudes towards disclosure and relationship to donor offspring among a national cohort of identity-release oocyte and sperm donors. Hum Reprod 2014; 29: 1978-86.

[12] Aballea P, Burstin A, Guedj J. [State of affairs and perspectives on oocyte donation in France] 2011 Report volume I. French.

http://www.ladocumentationfrancaise.fr/var/storage/rapports-publics/114000113.pdf. 
Figure Caption

Table 1: Demographic characteristics $(N=53)^{a}$

\begin{tabular}{|c|c|c|}
\hline & $n$ & $\%$ \\
\hline \multicolumn{3}{|l|}{ Gender } \\
\hline Man & 27 & 50.9 \\
\hline Woman & 26 & 49.1 \\
\hline \multicolumn{3}{|l|}{ Age $^{\mathrm{a}}$} \\
\hline $25-29$ years & 8 & 16.0 \\
\hline 30-34 years & 27 & 54.0 \\
\hline $35-39$ years & 10 & 20.0 \\
\hline 40-43 years & 5 & 10.0 \\
\hline Mean (M edian) & \multicolumn{2}{|l|}{$33.4(33)$} \\
\hline \multicolumn{3}{|l|}{ Education $^{a}$} \\
\hline Primary education & 2 & 3.9 \\
\hline Secondary education & 19 & 37.3 \\
\hline University or college & 30 & 58.8 \\
\hline \multicolumn{3}{|l|}{ Current professional activity } \\
\hline Full-time employed & 40 & 75.5 \\
\hline Part-time employed & 6 & 11.3 \\
\hline Unemployed & 7 & 13.2 \\
\hline \multicolumn{3}{|l|}{ Number of children ${ }^{a}$} \\
\hline 1 & 41 & 83.7 \\
\hline$x^{2}$ & 7 & 14.3 \\
\hline 3 & 1 & 2.0 \\
\hline Familiarity with other... & & \\
\hline \multicolumn{3}{|l|}{... people whose children were conceived with donor gametes ${ }^{\text {a }}$} \\
\hline Yes & 29 & 55.8 \\
\hline No & 23 & 44.2 \\
\hline \multicolumn{3}{|l|}{... women who donated ${ }^{a}$} \\
\hline Yes & 6 & 11.8 \\
\hline No & 45 & 88.2 \\
\hline \multicolumn{3}{|l|}{ Reason to go to this centre ${ }^{b}$} \\
\hline A friend told me about it & 3 & 6.4 \\
\hline It is the closest and most convenient centre & 28 & 59.6 \\
\hline I heard that the waiting time for sperm was shorter & 3 & 6.4 \\
\hline I believe in the reciprocity system & 8 & 17.0 \\
\hline Other ${ }^{\mathrm{c}}$ & 13 & 27.7 \\
\hline
\end{tabular}

${ }^{a}$ Data missing for three cases for age, four cases for number of children, two for education, one for familiarity with other people whose children were conceived with donor gametes, 2 for familiarity with other women who donated.

${ }^{\mathrm{b}}$ Respondents could select more than one option.

' Reasons stated were 'it was recommended by a physician' (7); 'I needed a donation' (2); 'have conceived a child' (1); 'I have donated' (1); 'second time we ask for donation' (1), 'positive experience with same donor' (1). 
Table 2: Attitudes towards gamete donation and the reciprocity system ( $N=53$ )

\begin{tabular}{|c|c|c|c|c|c|c|c|c|}
\hline & \multicolumn{6}{|c|}{ All respondents } & \multicolumn{2}{|l|}{ Gender } \\
\hline & \multicolumn{2}{|c|}{$\begin{array}{l}\text { (totally) } \\
\text { agree }\end{array}$} & \multicolumn{2}{|c|}{ neutral } & \multicolumn{2}{|c|}{$\begin{array}{l}\text { (totally) } \\
\text { disagree }\end{array}$} & \multirow{2}{*}{$\begin{array}{l}\text { Woman } \\
\%^{\mathrm{a}}\end{array}$} & \multirow{2}{*}{$\begin{array}{l}\text { Man } \\
\%^{a}\end{array}$} \\
\hline & $\mathrm{n}$ & $\%$ & $\mathrm{n}$ & $\%$ & $\mathrm{n}$ & $\%$ & & \\
\hline \multicolumn{9}{|l|}{ Reciprocity } \\
\hline $\begin{array}{l}\text { I prefer to wait longer than (let my } \\
\text { partner) donate. }\end{array}$ & 2 & 3.8 & 17 & 32.1 & 34 & 64.2 & 0.0 & 7.4 \\
\hline $\begin{array}{l}\text { I would mainly donate to help my } \\
\text { partner/l believe that my partner would } \\
\text { mainly donate to help me. }\end{array}$ & 8 & 15.4 & 9 & 17.3 & 35 & 67.3 & 12.0 & 18.5 \\
\hline $\begin{array}{l}\text { I would not (let my partner) donate if we } \\
\text { would not receive other gametes in } \\
\text { return. }\end{array}$ & 3 & 5.8 & 6 & 11.5 & 43 & 82.7 & 7.7 & 3.8 \\
\hline $\begin{array}{l}\text { I/my partner would not donate if we } \\
\text { would not receive treatment sooner. }{ }^{b}\end{array}$ & 5 & 9.6 & 8 & 15.4 & 39 & 75.0 & 11.5 & 7.7 \\
\hline $\begin{array}{l}\text { I feel that we should give something } \\
\text { back. }\end{array}$ & 26 & 49.1 & 6 & 11.3 & 21 & 39.6 & 42.3 & 55.6 \\
\hline $\begin{array}{l}\text { I believe that everyone should contribute } \\
\text { to the system. }{ }^{\text {b }}\end{array}$ & 21 & 40.4 & 17 & 32.7 & 14 & 26.9 & 44.0 & 37.0 \\
\hline \multicolumn{9}{|l|}{ Effort } \\
\hline $\begin{array}{l}\text { Donating eggs is an extra burden on top } \\
\text { of our own treatment. }\end{array}$ & 19 & 35.8 & 7 & 13.2 & 27 & 50.9 & 46.2 & 25.9 \\
\hline Donating eggs is a big effort for me/her. & 23 & 43.4 & 9 & 17.0 & 21 & 39.6 & 34.6 & 51.9 \\
\hline \multicolumn{9}{|l|}{ Feelings and beliefs } \\
\hline $\begin{array}{l}\text { I am very concerned that we will not get } \\
\text { sperm in time. }{ }^{\text {b }}\end{array}$ & 5 & 10.0 & 13 & 26.0 & 32 & 64.0 & 12.5 & 7.7 \\
\hline $\begin{array}{l}\text { I fear that donating eggs reduces our } \\
\text { own changes of getting pregnant. }\end{array}$ & 10 & 19.2 & 7 & 13.5 & 35 & 67.3 & 26.9 & 11.5 \\
\hline $\begin{array}{l}\text { I believe that donating eggs will have } \\
\text { negative effects on my/her health. }{ }^{\mathrm{b}}\end{array}$ & 2 & 3.9 & 5 & 9.8 & 44 & 86.3 & 8.0 & 0.0 \\
\hline \multicolumn{9}{|l|}{ Beliefs about result of the donation } \\
\hline $\begin{array}{l}\text { I would often think of the woman who } \\
\text { would receive my/ her eggs. }\end{array}$ & 12 & 22.6 & 17 & 32.1 & 24 & 45.3 & $42.3^{* * *}$ & 3.7 \\
\hline $\begin{array}{l}\text { I would often think of the child who may } \\
\text { result from my/her eggs. }\end{array}$ & 9 & 17.0 & 12 & 22.6 & 32 & 60.4 & $30.8^{*}$ & 3.7 \\
\hline $\begin{array}{l}\text { I would like to know whether a child was } \\
\text { born from my/her donation. }{ }^{\text {b }}\end{array}$ & 13 & 25.0 & 8 & 15.4 & 31 & 59.6 & $42.3^{* *}$ & 7.7 \\
\hline \multicolumn{9}{|l|}{ Disclosure and approval of others } \\
\hline $\begin{array}{l}\text { I will not tell anyone that we used donor } \\
\text { sperm. }{ }^{\text {b }}\end{array}$ & 5 & 9.6 & 8 & 15.4 & 39 & 75.0 & 7.7 & 11.5 \\
\hline $\begin{array}{l}\text { I will not tell anyone that I/my partner } \\
\text { donated eggs. }\end{array}$ & 3 & 5.7 & 8 & 15.1 & 42 & 79.2 & 3.8 & 7.4 \\
\hline $\begin{array}{l}\text { If told, my friends and family would } \\
\text { approve of me/my partner donating } \\
\text { eggs. }{ }^{b}\end{array}$ & 36 & 69.2 & 10 & 19.2 & 6 & 11.5 & 65.4 & 73.1 \\
\hline \multicolumn{9}{|l|}{ Anonymity } \\
\hline $\begin{array}{l}\text { Anonymity is a necessary condition for us } \\
\text { to donate. }\end{array}$ & 36 & 69.2 & 9 & 17.3 & 7 & 13.5 & 65.4 & 73.1 \\
\hline $\begin{array}{l}\text { I think that the child who results from } \\
\text { my/her donation should be able to know } \\
\text { me/her. }\end{array}$ & 2 & 3.8 & 11 & 21.2 & 39 & 75.0 & 3.8 & 3.8 \\
\hline $\begin{array}{l}\text { I would like to know the child who results } \\
\text { from my/her donation. }\end{array}$ & 1 & 1.9 & 7 & 13.5 & 44 & 84.6 & 3.8 & 0.0 \\
\hline
\end{tabular}


a Percentage of respondents agreeing or totally agreeing.

${ }^{b}$ Data missing for one case except for the following two statements: 'I believe that donating eggs will have negative effects on my/her health' (data missing in two cases); 'I am very concerned that we will not get sperm in time' (data missing in 3 cases)

$* p \leq 0.05 ; * * p \leq 0.01 ; * * * p \leq 0.001$. 
Table 3. Reasons to participate in the reciprocity system $(\mathrm{N}=53)$

\begin{tabular}{|c|c|c|c|c|c|c|c|c|}
\hline & \multicolumn{6}{|c|}{ All respondents } & \multicolumn{2}{|l|}{ Gender } \\
\hline & \multicolumn{2}{|c|}{$\begin{array}{l}\text { (Very) } \\
\text { unimportant }\end{array}$} & \multicolumn{2}{|c|}{ neutral } & \multicolumn{2}{|c|}{$\begin{array}{l}\text { (Very) } \\
\text { important }\end{array}$} & Woman & Man \\
\hline & $\mathrm{n}$ & $\%$ & $\mathrm{n}$ & $\%$ & $\mathrm{n}$ & $\%$ & $\%^{\mathrm{a}}$ & $\%^{a}$ \\
\hline To obtain faster treatment & 21 & 39.6 & 19 & 35.8 & 13 & 24.5 & 34.6 & 14.8 \\
\hline To help others ${ }^{b}$ & 2 & 3.8 & 1 & 1.9 & 49 & 94.2 & 92.3 & 96.2 \\
\hline To give something back ${ }^{b}$ & 15 & 28.8 & 6 & 11.5 & 31 & 59.6 & 61.5 & 57.7 \\
\hline To obtain the sperm I need ${ }^{b}$ & 30 & 60.0 & 6 & 12.0 & 14 & 28.0 & 36.0 & 20.0 \\
\hline
\end{tabular}

a percentage of respondents finding this reason important or very important.

${ }^{b}$ Data missing for one case except for the reason: 'To obtain the sperm I need' (data missing in 3 cases) 